Malaysian Journal of Fundamental and Applied Sciences

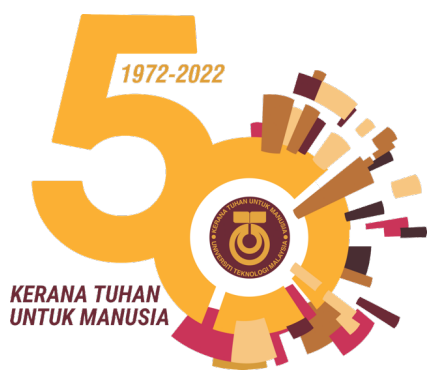

\title{
Identification of Pseudomonas aeruginosa
} Strains Isolated from Dorper Sheep Milk with Subclinical-mastitis Infection by Uniplex PCR using 16S rRNA, lasl/R, gyrB and ecfX Genes

\author{
Amirah Wan-Azemin, Nadiawati Alias*, Asmad Kari \\ Faculty of Bioresources and Food Industry, Universiti Sultan Zainal Abidin, Besut \\ Campus, 22200 Besut, Terengganu
}

Abstract Pseudomonas aeruginosa is an opportunistic and versatile pathogenic bacterium that can adapt in various environmental condition, which play a role in multiple virulence factor and resistance to antibiotics. Moreover, molecular identification techniques using single target gene is more susceptible to error and false positive. Thus, the detection of this strain with high specificity and sensitivity is crucial in order to control this pathogenic bacterium. The aim of this study was to evaluate six bacterial strains $(13-1,66-1,00-1,46-1,10-R$ and $67-1)$ isolated from Dorper sheep milk and $P$. aeruginosa ATCC strains (ATCC BAA-2108) for prompt identification of the strains based on uniplex polymerase chain reaction which targeting PA-SS, PA-GS, lasI/R, gyrB and ecfX genes. In the present study, the Dorper sheep milk's samples $(n=32)$ were collected and tested with California mastitis test (CMT). Out of 32 milk's samples, six of the samples were detected with strong mastitis, and thus were continued with inoculation process on selective media Pseudomonas Agar $\mathrm{P}$ (for pyocyanin) or $\mathrm{F}$ (fluorescein) and MacConkey agar for differentiation. After extraction of the bacterial chromosomal DNA, uniplex PCR amplification were carried out by using 16S rRNA (PA-SS and PA-GS) primers and specific $P$. aeruginosa genes (lasl/R, gyrB and ecfX) primers. The specificity of the primers was also examined by non-Pseudomonas species as a control for data comparison. Sequence analysis has revealed that six of the isolated samples were confirmed as $P$. aeruginosa strains with the respective genes sequence confirmed by BLAST and Clustal Omega. From this study, lasl/R, gyrB and ecfX were highly reliable primers with the percentage of identification of more than $95.0 \%$ as compared to PA-SS and PA-GS which were less than $90.0 \%$. This study concludes that highly specific and sensitive assay has been developed using lasI/R, gyrB and ecfX targeted genes for the detection of $P$. aeruginosa strains isolated from fresh sheep milk samples.

*For correspondence: nadiawati@unisza.edu.my

Received: 30 Jun 2021

Accepted: 17 Nov 2021

(C) Copyright Azemin et al.

This article is distributed under the terms of the

Creative Commons

Attribution License, which

permits unrestricted use and redistribution provided that

the original author and

source are credited.

\section{Introduction}

Pseudomonas aeruginosa is considered the most common opportunistic pathogen able to survive in different environments including soil, plants, animal and capable of infecting both humans and animals [1]-[3]. It causes various nosocomial diseases worldwide associated with high rate of mortality and morbidity in hospitalized patients until can reach to $61 \%$ of mortality [4], [5]. This pathogen historically associated to various severe infectious diseases such as pneumonia, respiratory tract infections, wound infection, urinary tract infection and outbreak infections of foodborne related to raw milk sample consumption [6], [7]. Other than that, the multidrug resistant of $P$. aeruginosa also caused by rampant, misuse of antibiotics as growth promoter in animal farming and during treatment for animals infection [8], [9]. Hence, quick and accurate early detection of $P$. aeruginosa can be performed by polymerase chain 
reaction $(P C R)$ to control the spread of the bacterial disease outbreaks. PCR is a rapid and sensitive technique for pathogenic bacterial identification in term of accuracy, specificity and reliability [10]. However, there is a major factor need to be highlighted in PCR assay that can lead to major problem. The application of a single target gene during PCR assay may lead to unexpected error including cross reactions with other bacterial species and false-negative or false-positive results attributed to sequence variation [5], [11]. Robust assessment of these species-specific target genes for determination of $P$. aeruginosa are therefore crucial, since misunderstanding at early detection of this bacterial species can lead to poor and misinterpretation of data and treatment approach animal and human.

GryB and ecfX genes were important virulence genes in PCR to detect the pathogenicity of $P$. aeruginosa [4], [10], [12] [11], [13]. 722F/899R gyrB is primer designed by [14], [15] that used for identification unique sequence in $P$. aeruginosa. While, ecfX gene is known as a species-specific target and reliable for identification marker of $P$. aeruginosa [4], [11], [13], [16], [17]. Lasl is knowns one of quorum sensing (QS) gene which is exclusive, specific and conserved for each bacterial species including $P$. aeruginosa strains [5], [18]. Moreover, Lasl act as virulence key regulatory system for $P$. aeruginosa species [4], [19]-[21]. Other than that, LasR also related to $Q S$ gene which play a role for identification $P$. aeruginosa and could be a reliable for rapid identification of $P$. aeruginosa in samples [22].Thus, given the important of these genes in the pathogenicity of $P$. aeruginosa, these genes are ideally suited as target markers for quick and sensitive identification of $P$. aeruginosa species in milk samples of sheep. Herein, the aim of this study was to identify $P$. aeruginosa isolates from Dorper's milk by PCR approaches using different types of target genes including PA-SS, PG-GS, Lasl/R, gyrB and ecfX.

\section{Materials and methods}

\section{Bacterial strains}

Six bacterial isolates (13-1, 66-1, 00-1, 46-1, 10-R and 67-1) from Dorper milk samples which were positive for mastitis infection were selected as described by [23]. All samples were retrieved from BesutSetiu Agropolitan Farm (BSA), Terengganu. In this study $P$. aeruginosa strain BAA-2108 was used as a control strain. All isolates were differentiated using selective media including MacConkey Agar and Pseudomonas Agar P (for pyocyanin) or F (fluorescein) [10].

\section{DNA Extraction}

Genomic DNA was extracted using trizol reagent (Invitrogen, USA) according to the manufacturer's protocol. DNA concentration and its purity were measured using UV-Spectrophotometer (Shimadzu, Japan).

\section{Primer Design}

Specific primer sequences of PA-SS, PA-GS, Lasl/R, gyrB and ecfX genes were as listed on Table 1 as according to [4].

\section{Application of Polymerase chain reaction (PCR) with uniplex assay}

PCR amplification was performed for detection based on 16S rDNA gene and identification of isolate samples from Dorper milk using specific primers including PA-SS, PA-GS, gyrB, Lasl/R and ecfX genes. The PCR master mix reaction was prepared in $50 \mu \mathrm{L}$ total reaction consists of $25 \mu \mathrm{L}$ of GoTaq mix (Promega, USA) reaction mixture [2.5 $\mu \mathrm{L}$ of 10X PCR buffer, $5 \mathrm{U}$ of Taq DNA polymerase, $2.5 \mathrm{mM}$ of $\mathrm{MgCl}_{2}, 0.4 \mathrm{mM}$ of each dNTPs],100 ng template DNA and 10 pmol of each primer $(10 \mu \mathrm{M})$. The PCR amplification cycles for each primer used were tabulated in Table 1. Following PCR amplification, $10 \mu \mathrm{L}$ of amplified product from each reaction and a DNA molecular-weight marker (1kb DNA ladder) were examined by electrophoresis in a $1 \%$ agarose gel. Gels were visualized under UV illumination using a gel documentation image analysis system (Fujifilm). The PCR products for all samples were purified by Wizard $^{\circledR}$ SV Gel and PCR Clean-Up System (Promega, USA) for DNA sequencing services at $1^{\text {st }}$ BASE Laboratory (M) Sdn Bhd.

\section{PCR primer specificity}

The specificity of the primer pairs including PA-SS, PA-GS, Lasl/R, gyrB and ecfX genes (Table 1) to Pseudomonas aeruginosa was tested by using Escherichia coli, Staphylococcus aureus, Bacillus cereus, Paenibacillus barcinonensis and Amycolatopsis orientalis acting as controls. PCR amplification were performed according to the method stated in Section 2.4 . 
Table 1. List of $16 \mathrm{~S}$ rDNA-based primer sets for the specific detection of Pseudomonas aeruginosa species.

\begin{tabular}{|c|c|c|c|c|}
\hline Primer & Sequence (5'-3') & Target & $\begin{array}{l}\text { Amplicon } \\
\text { size (bp) }\end{array}$ & PCR cycling conditions \\
\hline \multirow{3}{*}{ PA-SS } & F: GGGGGATCTTCGGACCTCA & & & $35 \times 94^{\circ} \mathrm{C}$ for $1 \mathrm{~min}$ \\
\hline & R: TCCTTAGAGTGCCCACCCG & $P$. aeruginosa strain & 956 & $60^{\circ} \mathrm{C}$ for $1 \mathrm{~min}$ \\
\hline & & & & $72^{\circ} \mathrm{C}$ for $2 \mathrm{~min}$ \\
\hline \multirow{3}{*}{ PA-GS } & F: GACGGGTGAGTAATGCCTA & & & $35 \times 94^{\circ} \mathrm{C}$ for $1 \mathrm{~min}$ \\
\hline & R: CACTGGTGTTCCTTCCTATA & Pseudomonas & 618 & $59^{\circ} \mathrm{C}$ for $1 \mathrm{~min}$ \\
\hline & & & & $72^{\circ} \mathrm{C}$ for $2 \min$ \\
\hline \multirow{3}{*}{ gyrB-a } & 722F : GGCGTGGGTGTGGAAGTC & & & $35 \times 94^{\circ} \mathrm{C}$ for $1 \mathrm{~min}$ \\
\hline & 899R:TGGTGGCGATCTTGAACTTCTT & gyrB & 190 & $60^{\circ} \mathrm{C}$ for $30 \mathrm{~s}$ \\
\hline & & & & $72^{\circ} \mathrm{C}$ for $1 \mathrm{~min}$ \\
\hline \multirow{3}{*}{ gyrB-b } & F:CCTGACCATCCGTCGCCACAAC & & & $35 \times 95^{\circ} \mathrm{C}$ for $30 \mathrm{~s}$ \\
\hline & R: CGCAGCAGGATGCCGACGCC & & 222 & $57^{\circ} \mathrm{C}$ for $30 \mathrm{~s}$ \\
\hline & & & & $72^{\circ} \mathrm{C}$ for $30 \mathrm{~s}$ \\
\hline \multirow{3}{*}{ Lasl-a } & F: ATGATCGTACAAATTGGTCGG & & & $35 \times 95^{\circ} \mathrm{C}$ for $30 \mathrm{~s}$ \\
\hline & R. GTCATGAAACCGCCAGTC & Lasl & 600 & $57^{\circ} \mathrm{C}$ for $30 \mathrm{~s}$ \\
\hline & R: GICAIGAAACCGCCAGIC & & & $72^{\circ} \mathrm{C}$ for $30 \mathrm{~s}$ \\
\hline \multirow{3}{*}{ LasI-b } & F: CGTGCTCAAGTGTTCAAGG & & & $35 \times 95^{\circ} \mathrm{C}$ for $30 \mathrm{~s}$ \\
\hline & R: TACAGTCGGAAAAGCCCAG & & 295 & $57^{\circ} \mathrm{C}$ for $30 \mathrm{~s}$ \\
\hline & R: IACAGICGGAAAAGCCCAG & & & $72^{\circ} \mathrm{C}$ for $30 \mathrm{~s}$ \\
\hline \multirow{3}{*}{ LasR } & F: ATGGCCTTGGTTGACGGT & & & $35 \times 95^{\circ} \mathrm{C}$ for $30 \mathrm{~s}$ \\
\hline & R: GCAAGATCAGAGAGTAATAAGACCC & LasR & 700 & $57^{\circ} \mathrm{C}$ for $30 \mathrm{~s}$ \\
\hline & & & & $72^{\circ} \mathrm{C}$ for $30 \mathrm{~s}$ \\
\hline \multirow{3}{*}{ ecfX } & F: ATGGATGAGCGCTTCCGTG & & & $35 \times 95^{\circ} \mathrm{C}$ for $30 \mathrm{~s}$ \\
\hline & R: TCATCCTTCGCСTCССTG & ecfX & 528 & $57^{\circ} \mathrm{C}$ for $30 \mathrm{~s}$ \\
\hline & & & & $72^{\circ} \mathrm{C}$ for $30 \mathrm{~s}$ \\
\hline
\end{tabular}

Initial denaturing step of $95^{\circ} \mathrm{C}$ for $5 \mathrm{~min}$ and final extension of $72^{\circ} \mathrm{C}$ for $5 \mathrm{~min}$.

\section{Sequence analysis and identification of bacterial isolates}

All the sequencing results were proceeded to BLASTN analysis available at National Center Biotechnology Information (NCBI). As general rule-of-thumb, the accuracy recognition of unknown bacterial for genus and species level must achieved $95 \%$ or above for the sequence similarity [24]. For sequence alignment, CLUSTAL Omega software was used for sequence alignment and comparison. Phylogenetic tree was constructed using MEGA 11.0 software through the neighbor-joining method. The reported results in the study were represented as the mean values of triplicates \pm standard deviation.

\section{Results and discussion}

Mastitis or subclinical mastitis in sheep prevalently considered as infection cause by a number of opportunistic bacterial pathogens including Staphylococcus aureus, Escherichia coli, Streptococcus spp. and Pseudomonas spp. [25], [26]. Previous study has shown that $P$. aeruginosa unusually causes mastitis infection in milk's sample of sheep compared to other pathogens bacterial [27] and these bacterial were reported to contribute a minor infection among sheep [28]. However, an early detection of $P$. aeruginosa in milk's sample is important to avoid food-borne disease, food poisoning and microbial contamination in milk quality which could be harmful for consumer and prompt to the disease outbreak among community especially in dairy field [29], [30]. Phenotypic identification of $P$. aeruginosa was performed among twenty-four isolates from 32 milk's sample on selected $P$. aeruginosa medium such as Pseudomonas Agar $\mathrm{P}$ (for pyocyanin) or $\mathrm{F}$ (fluorescein) and MacConkey agar plates. Colonies growth from $P$. aeruginosa ATCC BAA-2108 and 24 isolates showed formation of mucoid colonies on MacConkey agar plates and a greenish blue color on Pseudomonas Agar $\mathrm{P}$ (for pyocyanin) or $\mathrm{F}$ (fluorescein) agar plates (see Figure 1) due to production of the pyocyanin and fluorescein pigments [10] 

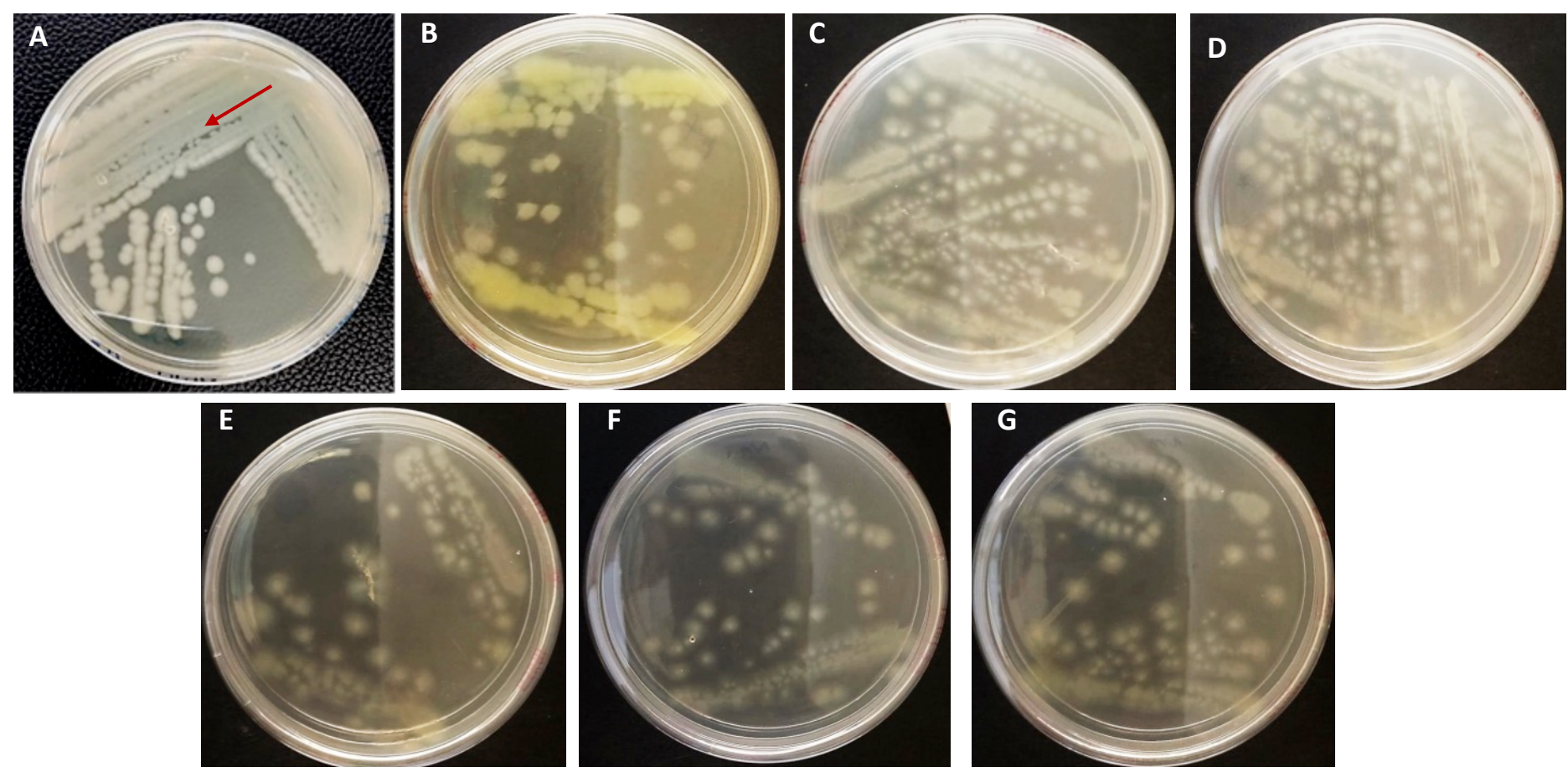

Figure 1. Colony morphology with bluish-green color (pyocyanin-at red arrow) from $P$. aeruginosa strains isolated from Dorper milk 's respectively on Pseudomonas agar, (A) ATCC BAA-2108; (B)13-1; (C) 66-1; (D) 00-1; (E) 46-1; (F) 10-R; (G) 67-1. The bluish-green or reddish-brown coloration is observed for all six isolate samples and ATCC BAA-2108 as a control strain.

Furthermore, accurate identification of $P$. aeruginosa from milk's sample infected with subclinical mastitis is critical in order to manage proper treatments to evade antibiotic resistance strains in human or animal. Previously, [10] and [31] reported that $P$. aeruginosa has developed resistant intrinsically to all effective antibiotic drugs. This $P$. aeruginosa are notably challenging and becoming dominant compared to others bacteria [3]. Sustained infection by $P$. aeruginosa is usually due to poor prognostic indicator used in low colony number of this species in milk's sample [32], [33] as well as the phenotypic methods used usually lengthy and required validation test due to the instability of this bacterium [10].

Besides, biochemical test commonly required longest time at least incubation from 18 to 48 hours to obtain results and the accuracy of the results may depend on sufficient growth in the test system [12], [34]. Hence, the accurate identification of $P$. aeruginosa isolated from milk's sample by molecular approach like PCR technique played a significant role to detect this pathogenic strain of $P$. aeruginosa present in milk's sample. This approach has become superior to phenotypic method for the identification $P$. aeruginosa and this may reduce unnecessary antibiotics treatment [31], [35]. PCR technique is one of the potential method used in identification of microbial species precisely by amplified the unique gene sequences for specific organism in food samples [31], [36]. In recent study, DNA were extracted from 24 isolated strains, $P$. aeruginosa ATCC strain (BAA-2108) and non-pseudomonas including Escherichia coli, Staphylococcus aureus, Bacillus cereus, Paenibacillus barcinonensis and Amycolatopsis orientalis for comparison purpose. The identities of the isolates bacterial from milk's samples were confirmed through amplicon of PA-SS (956bp) [37], PA-GS (618bp) [37], gyrB-a (190bp) [14], gyrB-b (222bp) [4], Lasl-a (600bp) [4], Lasl-b (295bp) [38], LasR (700bp) [4] and ecfX (528bp)[13] gene fragments, respectively.

In this study, the first primer pair of PA-SS-F and PA-SS-R was anticipated to amplify $P$. aeruginosa as many studies targeted the same gene for identification of $P$. aeruginosa shown in Table 1 [37]. The second primer pair of PA-GS-F and PA-GS-R was referred from previous study by [37] to amplify Pseudomonas genus (see Table 1). Amplified products at $956 \mathrm{bp}$ of PA-SS and $618 \mathrm{bp}$ of PA-GS which are both the most employed primers reported in the literature [37], and the uniform yield presented in Figure 2. However, only six isolates from the 24 bacterial isolates from six milk's sample with strong mastitis infection and $P$. aeruginosa ATCC strain (BAA-2108) were detected with corrected fragment at 956bp for PA-SS and at 618bp for PA-GS shown in Figure 2 and Table 2. The results obtained were 
accordance with the previous study by [39] which managed to screen $18.1 \%$ of $P$. aeruginosa strains using both PA-SS and PA-GS genes from hospital samples with patients with cystic fibrosis.

The sensitivity of each PCR assay using PA-SS primer pair for $P$. aeruginosa BAA-2108 (ATCC strain) was $100.0 \%$. Whilst the similarity with $P$. aeruginosa strains for four isolate samples $(13-1,10-\mathrm{R}, 66-1$ and $00-1$ ) were $99.8 \%, 98.8 \%, 98.0 \%$ and $97.3 \%$ with query sequence covered between $97 \%$ to $99 \%$, except for two isolates (46-1 and 67-1) which showed $88.0 \%$ and $91.0 \%$ similarity with query sequence covered $87 \%$ and $99 \%$, respectively. Besides, results presented using PA-GS primer pair for $P$. aeruginosa ATCC strain (BAA-2108) was $99.5 \%$ similarity and six isolates (13-1, 46-1, 10-R, 66-1, 00-1 and $67-1$ ) were $100 \%, 99.5 \%, 99.5 \%, 99.5 \%, 95.1 \%$ and $99.3 \%$ similarity with query sequence covered between $81 \%$ to $99 \%$ against $\mathrm{NCBI}$ database, respectively (Table 2). Though, the PCR amplification for both PA-SS and PA-GS genes of non-pseudomonas species had shown a positive result with present of specific band at the corrected size (Table 2). However, two isolates (46-1 and 67-1) showed less than 95.0\% similarity when using species specific primer (PA-SS) and thus showed different species for $P$. aeruginosa strains as stated in Table 2. This results are in agreement with previous study by [13], the DNA extracted of PCR product of PA-SS gene yielded less than $95.0 \%$ similarity (which is $86.0 \%$ similarity) against one of $P$. aeruginosa strain in GeneBank database. This can be considered that the isolates were not derived from a $P$. aeruginosa strain. Hence, the multiple potential target genes are needed in order to confirm the identification of $P$. aeruginosa strain among isolate samples. Besides that, it is interesting to note that, from the PCR amplification performed on non-pseudomonas species for both PA-SS and PA-GS genes, the results had shown a specific band at the correct size (956bp) (Figure 2). This showed that PA-SS was not a specific primer for identification of $P$. aeruginosa strains as stated by [11] reported that PA-SS or coded as Pa16S-PCR assay was cross-reactions with non- $P$. aeruginosa species which may be due to the $P$. aeruginosa strains having sequence variation within the primer or probe site of one of the gene targets and [40] stated that $P$. aeruginosa also known to exhibit extensive genetic diversity that make broad problem affecting the success of molecular diagnostic assay. Thus, supplemental test using multiple target genes would be warranted due to 16S rRNA gene of $P$. aeruginosa was commonly used but was not feasible to develop highly specific primer set using this gene because their high similarities of the 16S rRNA gene sequences [14].

Furthermore, previous study by [11] reported false-positive result when using PA-SS gene and crossreaction with non- $P$. aeruginosa were observed for PCR products sequencing targeting the $P$. aeruginosa PA-SS gene [11]. This results occur may be due to the $P$. aeruginosa have high number of genome and has highly polymorphic nature which probably influence the reliability and specificity of the PCR [4], [5]. Thus, this limitation of using PA-SS primer pair may lead to the use of multiple species-specific genes of $P$. aeruginosa for more accurate sequencing result. Previous study by [10] and [41] also stated that development of DNA-based technique specifically PCR and using more than one targeted gene for detection and identification of $P$. aeruginosa was important for better confirmation and assurance to reduce potential false negative results due to the variation of sequence in the primers. Therefore, targeting virulence genes for PCR assay such as gyrB-a gene (722F and 899R) [14] and gyrB-b [4] were significant for $P$. aeruginosa ATCC strain (BAA-2108) and six isolate samples (13-1, 46-1, 10-R, 66-1, 00-1 and 67-1).

Currently, application on gyrB target, 722F/899R gyrB was chosen as a species-specific gene target for $P$. aeruginosa detection since it has been reported previously [4], [11], [13], [16], [17] as a reliable identification marker for $P$. aeruginosa. Both gyrB-a and gyrB-b were found from $97.4 \%$ to $98.7 \%$ and $96.5 \%$ to $99.5 \%$ similarity with $P$. aeruginosa PA0750 strain shown in Figure 2 and Table 2, respectively. The results obtained in this study were comparable with previous studies by [42], [43] which indicate that this gyrB gene has conserved region presence in the genome of $P$. aeruginosa which presented about 99\% identical with PA01. The primer has unique sequence to $P$. aeruginosa as compared to other 57 strains of $P$ seudomonas species with high sensitivity and specificity (absence detection of other bacterial species) [14], [15]. 
MJFAS

Table 2. The top hit results of NCBI Blast using 8 different primer pairs for 6 bacterial strains against $P$. aeruginosa BAA-2108.

\begin{tabular}{|c|c|c|c|c|c|c|c|c|c|c|c|c|}
\hline \multirow{3}{*}{$\begin{array}{l}\text { Bacterial } \\
\text { species }\end{array}$} & \multicolumn{12}{|c|}{ BLASTN GeneBank Database } \\
\hline & \multicolumn{3}{|c|}{ PA-GS } & \multicolumn{3}{|c|}{ PA-SS } & \multicolumn{3}{|c|}{ gyrB-a } & \multicolumn{3}{|c|}{ gyrB-b } \\
\hline & $\begin{array}{c}\text { Identify } \\
(\%)\end{array}$ & $\begin{array}{c}\text { Query } \\
\text { cover } \\
(\%)\end{array}$ & $\begin{array}{c}\text { Top } \\
\text { bacterium's } \\
\text { name }\end{array}$ & $\begin{array}{c}\text { Identify } \\
(\%)\end{array}$ & $\begin{array}{c}\text { Query } \\
\text { cover } \\
(\%)\end{array}$ & $\begin{array}{c}\text { Top } \\
\text { bacterium's } \\
\text { name }\end{array}$ & $\begin{array}{c}\text { Identify } \\
(\%)\end{array}$ & $\begin{array}{c}\text { Query } \\
\text { cover } \\
(\%)\end{array}$ & $\begin{array}{c}\text { Top } \\
\text { bacterium's } \\
\text { name }\end{array}$ & $\begin{array}{c}\text { Identify } \\
(\%)\end{array}$ & $\begin{array}{c}\text { Query } \\
\text { cover } \\
(\%)\end{array}$ & $\begin{array}{c}\text { Top } \\
\text { bacterium's } \\
\text { name }\end{array}$ \\
\hline $\begin{array}{c}P . \\
\text { aeruginosa } \\
\text { BAA-2108 }\end{array}$ & 99.5 & 99.0 & $\begin{array}{c}\text { P.aeruginosa } \\
\text { (PA0750,CD } \\
\text { N118, } \\
\text { DVT410) }\end{array}$ & 100.0 & 99.0 & $\begin{array}{c}\text { P.aeruginosa } \\
\text { (PA0750,CD } \\
\text { N118, } \\
\text { DVT410) }\end{array}$ & 98.1 & 95.0 & $\begin{array}{c}\text { P.aeruginosa } \\
\text { (PA0750, } \\
\text { DVT779, } \\
\text { DVT429) }\end{array}$ & 99.5 & 94.0 & $\begin{array}{l}\text { P.aeruginosa } \\
\text { (PA0750,CDN } \\
118, \text { DVT410) }\end{array}$ \\
\hline $13-1$ & 100.0 & 98.0 & $\begin{array}{c}\text { P.aeruginosa } \\
\text { (PA0750,CD } \\
\text { N118, } \\
\text { DVT410) }\end{array}$ & 99.8 & 97.0 & $\begin{array}{c}\text { P.aeruginosa } \\
\text { (PA0750,CD } \\
\text { N118, } \\
\text { DVT410) }\end{array}$ & 98.7 & 93.0 & $\begin{array}{c}\text { P.aeruginosa } \\
\text { (PA0750, } \\
\text { DVT779, } \\
\text { DVT429) }\end{array}$ & 96.9 & 47.0 & $\begin{array}{l}\text { P.aeruginosa } \\
\text { (PA0750,CDN } \\
\text { 118, DVT410) }\end{array}$ \\
\hline $46-1$ & 99.5 & 99.0 & $\begin{array}{l}\text { P.aeruginosa } \\
\text { (PA0750,CD } \\
\text { N118, } \\
\text { DVT410) }\end{array}$ & 88.0 & 87.0 & $\begin{array}{l}\text { P.aeruginosa } \\
\text { (PGSL03, } \\
\text { KAR21,H707 } \\
\text { ) }\end{array}$ & 98.7 & 93.0 & $\begin{array}{c}\text { P.aeruginosa } \\
\text { (PA0750, } \\
\text { DVT779, } \\
\text { DVT429) }\end{array}$ & 99.5 & 95.0 & $\begin{array}{l}\text { P.aeruginosa } \\
\text { (PA0750,CDN } \\
\text { 118, DVT410) }\end{array}$ \\
\hline $10-\mathrm{R}$ & 99.5 & 98.0 & $\begin{array}{l}\text { P.aeruginosa } \\
\text { (PA0750,CD } \\
\text { N118, } \\
\text { DVT410) }\end{array}$ & 98.8 & 99.0 & $\begin{array}{l}\text { P.aeruginosa } \\
\text { (PA0750,CD } \\
\text { N118, } \\
\text { DVT410) }\end{array}$ & 98.7 & 91.0 & $\begin{array}{c}\text { P.aeruginosa } \\
\text { (PA0750, } \\
\text { DVT779, } \\
\text { DVT429) }\end{array}$ & 98.4 & 96.0 & $\begin{array}{l}\text { P.aeruginosa } \\
\text { (PA0750,CDN } \\
\text { 118, DVT410) }\end{array}$ \\
\hline $66-1$ & 99.5 & 98.0 & $\begin{array}{l}\text { P.aeruginosa } \\
\text { (PA0750,CD } \\
\text { N118, } \\
\text { DVT410) }\end{array}$ & 98.0 & 98.0 & $\begin{array}{l}\text { P.aeruginosa } \\
\text { (PA0750,CD } \\
\text { N118, } \\
\text { DVT410) }\end{array}$ & 97.4 & 96.0 & $\begin{array}{c}\text { P.aeruginosa } \\
\text { (PA0750, } \\
\text { DVT779, } \\
\text { DVT429) }\end{array}$ & 98.0 & 99.0 & $\begin{array}{l}\text { P.aeruginosa } \\
\text { (PA0750,CDN } \\
\text { 118, DVT410) }\end{array}$ \\
\hline $00-1$ & 95.1 & 81.0 & $\begin{array}{c}\text { P.aeruginosa } \\
\text { (JM2LBA, } \\
\text { NAULM-2, } \\
\text { DSH10) }\end{array}$ & 97.3 & 95.0 & $\begin{array}{c}\text { P.aeruginosa } \\
\text { (JM2LBA, } \\
\text { NAULM-2, } \\
\text { DSH10) }\end{array}$ & 98.0 & 94.0 & $\begin{array}{c}\text { P.aeruginosa } \\
\text { (PA0750, } \\
\text { DVT779, } \\
\text { DVT429) }\end{array}$ & 96.5 & 97.0 & $\begin{array}{l}\text { P.aeruginosa } \\
\text { (PA0750,CDN } \\
\text { 118, DVT410) }\end{array}$ \\
\hline $67-1$ & 99.3 & 99.0 & $\begin{array}{c}\text { P.aeruginosa } \\
\text { (PA0750,CD } \\
\text { N118, } \\
\text { DVT410) }\end{array}$ & 91.0 & 99.0 & $\begin{array}{c}\text { P.aeruginosa } \\
\text { (YT12746,A } \\
\text { R442, } \\
\text { DHS01) }\end{array}$ & 98.7 & 95.0 & $\begin{array}{c}\text { P.aeruginosa } \\
\text { (PA0750, } \\
\text { DVT779, } \\
\text { DVT429) }\end{array}$ & 99.5 & 60.0 & $\begin{array}{l}\text { P.aeruginosa } \\
\text { (PA0750,CDN } \\
\text { 118, DVT410) }\end{array}$ \\
\hline
\end{tabular}


MJFAS

Table 2.(cont.) The top hit results of NCBI Blast using 8 different primer pairs for 6 bacterial strains against $P$. aeruginosa BAA-2108.

\begin{tabular}{|c|c|c|c|c|c|c|c|c|c|c|c|c|}
\hline \multirow{3}{*}{$\begin{array}{l}\text { Bacterial } \\
\text { species }\end{array}$} & \multicolumn{12}{|c|}{ BLASTN GeneBank Database } \\
\hline & \multicolumn{3}{|c|}{ Lasl-a } & \multicolumn{3}{|c|}{ Lasl-b } & \multicolumn{3}{|c|}{ LasR } & \multicolumn{3}{|c|}{ ecfX } \\
\hline & $\begin{array}{c}\text { Identify } \\
(\%)\end{array}$ & $\begin{array}{c}\text { Query } \\
\text { cover } \\
(\%)\end{array}$ & $\begin{array}{c}\text { Top } \\
\text { bacterium's } \\
\text { name }\end{array}$ & $\begin{array}{c}\text { Identify } \\
(\%)\end{array}$ & $\begin{array}{c}\text { Query } \\
\text { cover } \\
(\%)\end{array}$ & $\begin{array}{c}\text { Top } \\
\text { bacterium's } \\
\text { name }\end{array}$ & $\begin{array}{c}\text { Identify } \\
(\%)\end{array}$ & $\begin{array}{c}\text { Query } \\
\text { cover } \\
(\%)\end{array}$ & $\begin{array}{c}\text { Top } \\
\text { bacterium's } \\
\text { name }\end{array}$ & $\begin{array}{c}\text { Identify } \\
(\%)\end{array}$ & $\begin{array}{c}\text { Query } \\
\text { cover } \\
(\%)\end{array}$ & $\begin{array}{c}\text { Top } \\
\text { bacterium's } \\
\text { name }\end{array}$ \\
\hline $\begin{array}{c}P . \text { aeruginosa } \\
\text { BAA-2108 }\end{array}$ & 99.7 & 98.0 & $\begin{array}{c}\text { P.aeruginosa } \\
\text { (PA0750,CD } \\
\text { N118, } \\
\text { DVT410) }\end{array}$ & 99.6 & 95.0 & $\begin{array}{l}\text { P.aeruginosa } \\
\text { (PA0750,CD } \\
\text { N118, } \\
\text { DVT410) }\end{array}$ & 99.3 & 98.0 & $\begin{array}{c}\text { P.aeruginosa } \\
\text { (PA0750,CD } \\
\text { N118, } \\
\text { DVT410) }\end{array}$ & 99.2 & 99.0 & $\begin{array}{c}\text { P.aeruginosa } \\
\text { (PA0750,CDN1 } \\
\text { 18, DVT410) }\end{array}$ \\
\hline $13-1$ & 99.7 & 98.0 & $\begin{array}{l}\text { P.aeruginosa } \\
\text { (PA0750,CD } \\
\text { N118, } \\
\text { DVT410) }\end{array}$ & 99.2 & 98.0 & $\begin{array}{l}\text { P.aeruginosa } \\
\text { (PA0750,CD } \\
\text { N118, } \\
\text { DVT410) }\end{array}$ & 99.3 & 98.0 & $\begin{array}{c}\text { P.aeruginosa } \\
\text { (PA0750,CD } \\
\text { N118, } \\
\text { DVT410) }\end{array}$ & 99.6 & 98.0 & $\begin{array}{c}\text { P.aeruginosa } \\
\text { (PA0750,CDN1 } \\
\text { 18, DVT410) }\end{array}$ \\
\hline $46-1$ & 99.8 & 98.0 & $\begin{array}{l}\text { P.aeruginosa } \\
\text { (PA0750,CD } \\
\text { N118, } \\
\text { DVT410) }\end{array}$ & 99.6 & 98.0 & $\begin{array}{l}\text { P.aeruginosa } \\
\text { (PA0750,CD } \\
\text { N118, } \\
\text { DVT410) }\end{array}$ & 98.6 & 98.0 & $\begin{array}{c}\text { P.aeruginosa } \\
\text { (PA0750,CD } \\
\text { N118, } \\
\text { DVT410) }\end{array}$ & 99.4 & 99.0 & $\begin{array}{c}\text { P.aeruginosa } \\
\text { (PA0750,CDN1 } \\
\text { 18, DVT410) }\end{array}$ \\
\hline $10-\mathrm{R}$ & 98.9 & 87.0 & $\begin{array}{l}\text { P.aeruginosa } \\
\text { (PA0750,CD } \\
\text { N118, } \\
\text { DVT410) }\end{array}$ & 99.2 & 98.0 & $\begin{array}{l}\text { P.aeruginosa } \\
\text { (PA0750,CD } \\
\text { N118, } \\
\text { DVT410) }\end{array}$ & 99.4 & 100.0 & $\begin{array}{c}\text { P.aeruginosa } \\
\text { (PA0750,CD } \\
\text { N118, } \\
\text { DVT410) }\end{array}$ & 99.2 & 99.0 & $\begin{array}{c}\text { P.aeruginosa } \\
\text { (PA0750,CDN1 } \\
\text { 18, DVT410) }\end{array}$ \\
\hline $66-1$ & 99.8 & 98.0 & $\begin{array}{l}\text { P.aeruginosa } \\
\text { (PA0750,CD } \\
\text { N118, } \\
\text { DVT410) }\end{array}$ & 99.6 & 97.0 & $\begin{array}{l}\text { P.aeruginosa } \\
\text { (PA0750,CD } \\
\text { N118, } \\
\text { DVT410) }\end{array}$ & 99.4 & 97.0 & $\begin{array}{c}\text { P.aeruginosa } \\
\text { (PA0750,CD } \\
\text { N118, } \\
\text { DVT410) }\end{array}$ & 99.4 & 99.0 & $\begin{array}{c}\text { P.aeruginosa } \\
\text { (PA0750,CDN1 } \\
\text { 18, DVT410) }\end{array}$ \\
\hline $00-1$ & 99.3 & 99.0 & $\begin{array}{l}\text { P.aeruginosa } \\
\text { (PA0750,CD } \\
\text { N118, } \\
\text { DVT410) }\end{array}$ & 99.6 & 97.0 & $\begin{array}{l}\text { P.aeruginosa } \\
\text { (PA0750,CD } \\
\text { N118, } \\
\text { DVT410) }\end{array}$ & 99.3 & 98.0 & $\begin{array}{c}\text { P.aeruginosa } \\
\text { (PA0750,CD } \\
\text { N118, } \\
\text { DVT410) }\end{array}$ & 99.8 & 98.0 & $\begin{array}{c}\text { P.aeruginosa } \\
\text { (PA0750,CDN1 } \\
\text { 18, DVT410) }\end{array}$ \\
\hline $67-1$ & 99.7 & 98.0 & $\begin{array}{l}\text { P.aeruginosa } \\
\text { (PA0750,CD } \\
\text { N118, } \\
\text { DVT410) }\end{array}$ & 99.2 & 99.0 & $\begin{array}{l}\text { P.aeruginosa } \\
\text { (PA0750,CD } \\
\text { N118, } \\
\text { DVT410) }\end{array}$ & 99.5 & 98.0 & $\begin{array}{c}\text { P.aeruginosa } \\
\text { (PA0750,CD } \\
\text { N118, } \\
\text { DVT410) }\end{array}$ & 99.5 & 99.0 & $\begin{array}{c}\text { P.aeruginosa } \\
\text { (PA0750,CDN1 } \\
\text { 18, DVT410) }\end{array}$ \\
\hline
\end{tabular}



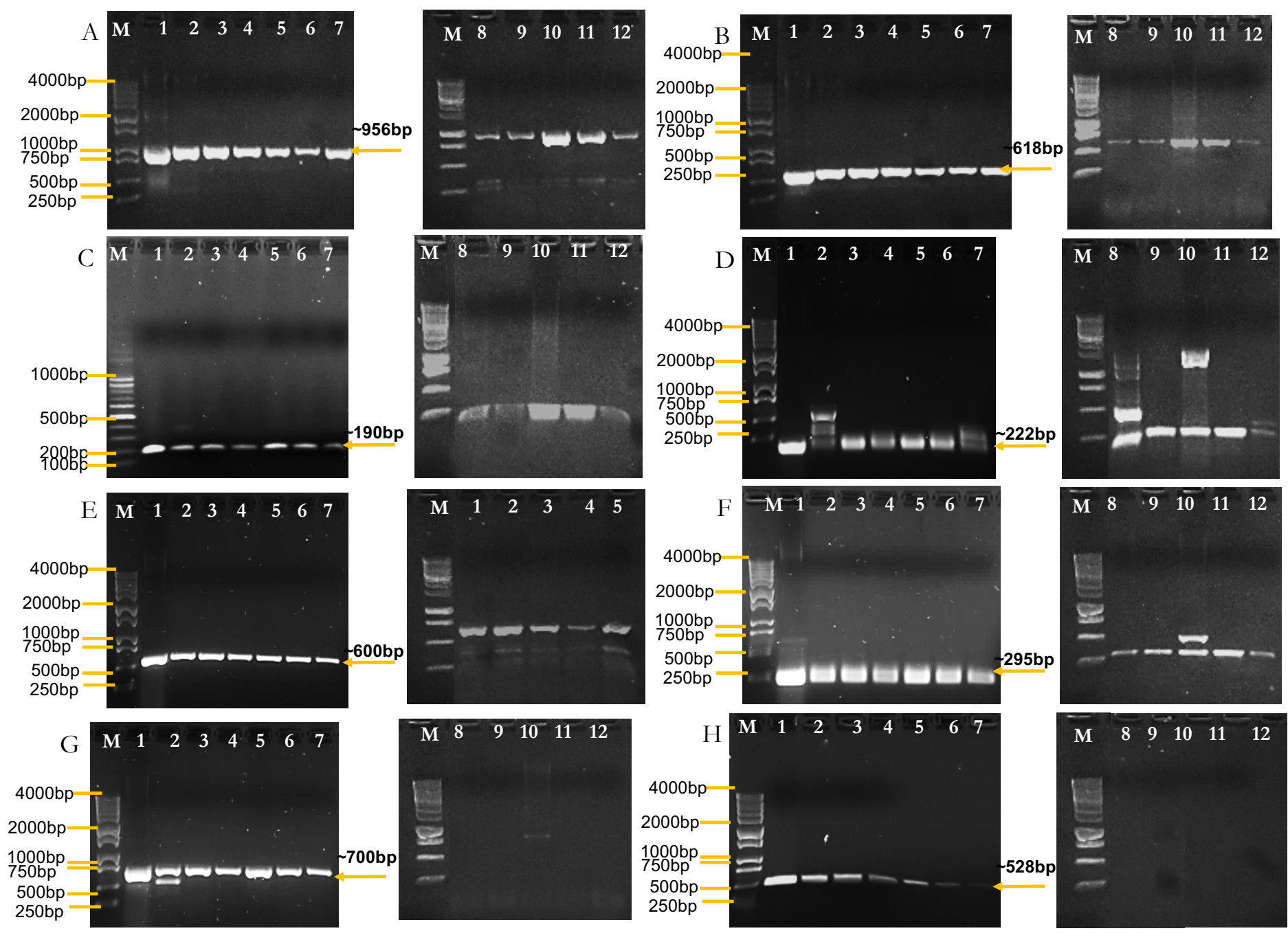

Figure 2. PCR amplifications of 8 targeted genes on $P$. aeruginosa BAA-2108, 6 bacterial isolates and 5 non- $P$. aeruginosa strains. (A) $P$. aeruginosa-specific primer PA-SS (956bp); (B) Pseudomonas genus-specific primer PA-GS (618bp); (C) gyrB-a (722F and 899R) (190bp); (D) gyrB-b (222bp); (E) Lasl-a (600bp); (F) Lasl-b (295bp); (G) LasR (700bp) and (H) ecfX (528bp). Lanes M,1kb DNA marker; lane 1, $P$. aeruginosa BAA-2108; lane 2, 13-1; lane 3, 46-1; lane 4, 10-R; lane 5, 66-1; lane 6, 00-1; Lane 7, 67-1; Lane 8, E. coli; Lane 9, B. cereus; Lane 10, P. barcinonensis; Lane 11, A. orientalis; Lane 12, S. aureus.

This study shows that high sensitivity of PCR product of both gyrB-a (722F and 899R) and gyrB-b primers pair in $P$. aeruginosa ATCC strain (BAA-2108) was $98.1 \%$ and $99.5 \%$ similarity, respectively. Besides, the percentage of similarity of gyrB-a (722F and $899 \mathrm{R})$ primer pairs for six isolate samples $(13-1,46-1$, $10-\mathrm{R}, 66-1,00-1$ and $67-1$ ) showed very high sensitivity which were $98.7 \%, 98.7 \%, 98.7 \%, 97.4 \%, 98.0 \%$ and $98.7 \%$ with query sequence covered from $91 \%$ to $96 \%$, respectively (Figure 2 and Table 2). While, sequencing results of using gyrB-b primer pair for six isolate samples (13-1, 46-1, 10-R, 66-1, 00-1 and $67-1$ ) were $96.9 \%, 99.5 \%, 98.4 \%, 98.0 \%, 96.5 \%$ and $99.5 \%$ similarity with query sequence covered from $47 \%$ to $99 \%$, respectively (Figure 2 and Table 2). Difference percentage of similarities in gyrB gene might be due to the factor of various kind place's condition and type of prevalence strains [44]-[46]. The presented gyrB gene plays an importance role in the DNA replication process and suitable for identification of $P$. aeruginosa [11], [47]. However, this study also showed the present of cross-reaction or false-positive/negative results indicated when there is present of gyrB gene at both fragments in agarose gel of non-Pseudomonas species shown in Figure 2. Therefore, another specific gene was essential in order for troubleshoot this problem due to the gyrB gene will produce DNA gyrase as an importance enzyme play an essential role in bacterial growth by involving in DNA replication, transcription and recombination [48]. 
Subsequently, this study also amplified PCR using both primer pair of Lasl-a (at 600bp) and Lasl-b (at $295 \mathrm{bp}$ ) in order to identify of $P$. aeruginosa as described by [4] and [38], respectively. Both studies reported that the amplicons produced by the Lasl-a and Lasl-b were observed only in $P$. aeruginosa isolates strain. Results in this study showed that $P$. aeruginosa ATCC BAA-2108 and six isolate samples (13-1, 46-1, 10-R, 66-1, 00-1 and 67-1) amplified product at 600bp of Lasl-a and 295bp of Lasl-b primer pairs which Lasl was known as the most pathogenicity genes of $P$. aeruginosa showed in Figure 2 . The similarity results of PCR assay using Lasl-a primer pairs for $P$. aeruginosa ATCC strain (BAA-2108) was $99.7 \%$. Whereas, the similarity results of six isolate samples $(13-1,46-1,10-R, 66-1,00-1$ and $67-1)$ were $99.7 \%, 99.8 \%, 98.9 \%, 99.8 \%, 99.3 \%$ and $99.7 \%$ with query sequence covered from $87 \%$ to $99 \%$, respectively (Figure 2 and Table 2). Besides, the similarity results presented using Lasl-b primer pairs of $P$. aeruginosa ATCC strain (BAA-2108) was $99.6 \%$ and were $99.2 \%, 99.6 \%, 99.2 \%, 99.6 \%, 99.6 \%$ and $99.2 \%$ with query sequence covered from $95 \%$ to $99 \%$ for six isolate samples $13-1,46-1,10-R, 66-1$, 00-1 and 67-1, respectively (Figure 2 and Table 1). The presence of amplified product at 295bp of Laslb primer pairs (Figure 2) was in accordance with previous study by [38] who described that the virulence factor such as Lasl-b at amplicon 295 bp was presented among $P$. aeruginosa strain with Lasl-b was $53.8 \%$ detected in their study. This study amplified corrected fragments of both Lasl (at 600 and 295bp) with high similarity among isolate samples against $P$. aeruginosa strains in NCBI GeneBank database. However, the specificity of using Lasl as specific primer for detection of $P$. aeruginosa is still questionable since the gene was also detected in Paenibacillus barcinonensis as stated in Figure 2.

On the other hand, $P$. aeruginosa ATCC BAA-2108 and six isolate samples $(13-1,46-1,10-R, 66-1,00-$ 1 and 67-1) also were identified using the amplification PCR of primer pairs of LasR. LasR protein is a key QS signal receptor since it acts as global and major transcriptional activator of $P$. aeruginosa QS and play a crucial role in the activation of many virulence genes. Moreover, previous study also found that a dominant-negative form of LasR can interfere with the production of proteases by $P$. aeruginosa strain [49]-[51]. The results in this study presented that among ATCC strain (BAA-2108) and isolate samples from Dorper's milk showed high sensitivity which is more than $99.0 \%$ similarity against $P$. aeruginosa strain NCBI GeneBank database. The sensitivity of PCR assay using LasR primer pair for $P$. aeruginosa ATCC strain (BAA-2108) was $99.3 \%$ similarity and six isolates sample $(13-1,46-1,10-R, 66-$ $1,00-1$ and $67-1$ ) were $99.3 \%, 98.6 \%, 99.4 \%, 99.4 \%, 99.3 \%$ and $99.5 \%$ similarity with $97 \%$ to $100 \%$ of the query sequence is covered, respectively (Figure 2 and Table 2). This results is in agreement with previous studies by [4] and [5], reported that the sensitivity of the LasR primer pair were shown as high as $100.0 \%$ similarity with $100.0 \%$ specificity where no false-positive results were observed among $P$. aeruginosa isolate strains.

Nevertheless, the PCR results for non- $P$. aeruginosa were negative and absence amplified LasR fragment as showed in Figure 2, which means that no cross-reaction or false-positive/negative results indicated. Thus, as tested in this study, LasR gene can be used as species-specific gene for $P$. aeruginosa as the gene has unique conserve sequence and specifically detected only in $P$. aeruginosa strain. Moreover, this study managed to produce higher similarity percentage against $P$. aeruginosa as compared to previous study by [22] which was at $81.3 \%$. Also reported by [52] the occurrences of LasR gene in $P$. aeruginosa were found reduced at $75.0 \%$ and $40.0 \%$ in India and Egypt. This reduction in detecting LasR gene may be due to the mutation in LasR gene which possibly generated the nonfunctional LasR gene [22].

Other than that, the amplification PCR by using ecfX primer pairs also were performed in this study according to the prevalence studies that reported the potential of using ecfX genes for detection of $P$. aeruginosa strains from Dorper's milk sheep have not been yet applied [13], [47], [53]. In this study, the amplified fragment product of ecfX primer pairs at $528 \mathrm{bp}$ were obtained for all six isolate samples and ATCC BAA-2108 strains (Figure 2), but not detected in non- $P$. aeruginosa strain (Figure 2). Besides, the results BLASTN analysis against GeneBank database shows that using ecfX primer pair for $P$. aeruginosa ATCC strain (BAA-2108) have an 99.2\% similarity and six isolate samples (13-1, 46-1, 10$\mathrm{R}, 66-1,00-1$ and $67-1$ ) were $99.6 \%, 99.4 \%, 99.2 \%, 99.4 \%, 99.8 \%$ and $99.5 \%$ similarity with query sequence covered from $98 \%$ to $99 \%$, respectively (Figure 2 and Table 2). The top hit of bacterium's names for all isolate strains was $P$. aeruginosa strain PA0750 and followed by $P$. aeruginosa strain CDN118 and DVT410. Therefore, the PCR amplification product using ecfX gene shows higher sensitivity more than $99.0 \%$ similarity in all isolate samples which indicates that ecfX gene was highly conserved and reliable gene in detection of $P$. aeruginosa in accordance with earlier studies [11]-[13]. Besides, no amplified PCR product was detected in non- $P$. aeruginosa isolates (Figure 2) which means no cross-reaction or false-positive/negative results presence. This finding is in agreement with previous study [16] reported that the ecfX gene was not present in any of the non- $P$. aeruginosa isolates of keratitis collected from cornea and was absence of cross-reaction or false-positive or -negative results when used ecfX gene targets in $P$. aeruginosa strains with non- $P$. aeruginosa isolates [11], [53]-[55]. Since both of these genes showed more species-specific primer for $P$. aeruginosa identification, a phylogenetic tree 
for all the bacterial isolates for LasR and ecfX genes were constructed as shown in Figure 3 . From the phylogenetic analysis, it indicated that the bacterial strains tested were identified as $P$. aeruginosa PA0750 strain with $100 \%$ similarity as also supported by the BLASTN analysis against NCBI database.

A

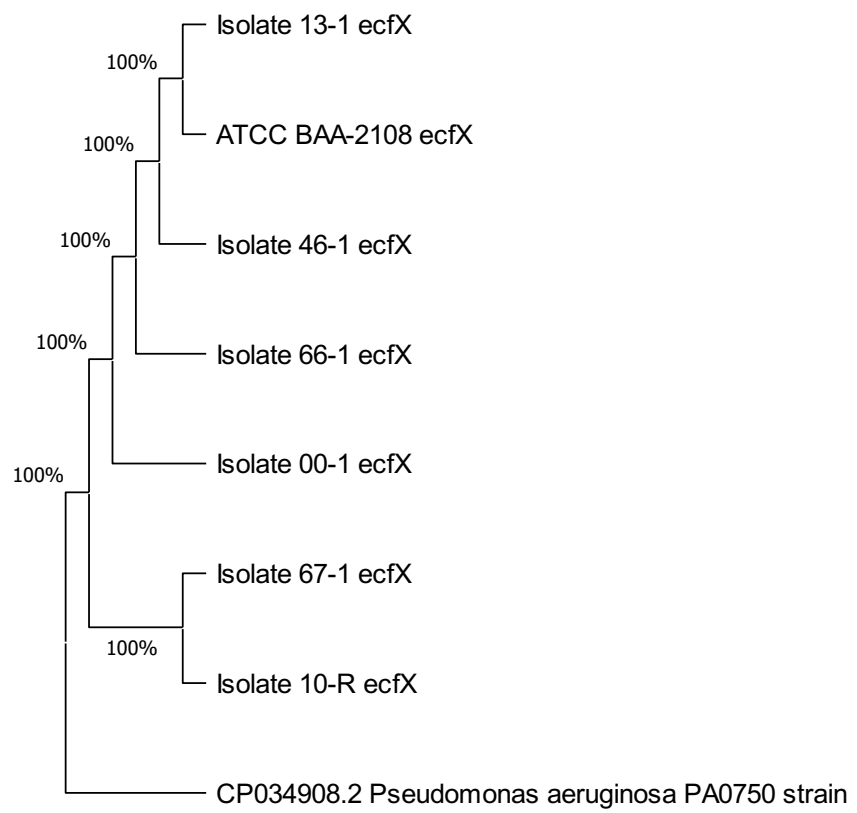

B

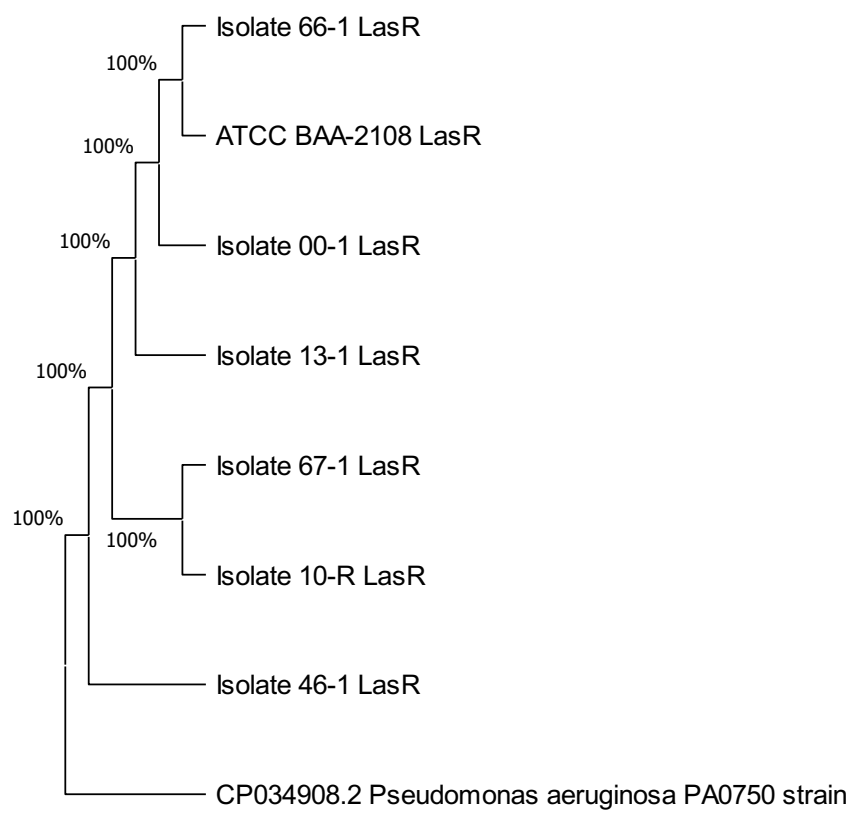

Figure 3. Phylogenetic analysis of (A) ecfX gene; (B) LasR gene for six bacterial isolates (13-1, 66-1, 00-1, 46-1, 10-R and 67-1) and $P$. aeruginosa ATCC BAA-2108 against $P$. aeruginosa PA0750 strain.

DNA sequencing analysis from the data obtained using multiple primer pairs targeted on all six samples isolate from Dorper's milk (13-1, 46-1, 10-R, 66-1, 00-1 and 67-1) have been confirmed with high similarity to $P$. aeruginosa strain PA0750 against the NCBI database. Notably, PA-SS, PA-GS, gyrB-a, gyrB-b, Lasl-a, Lasl-b targeted genes were not suitable to be used as species specific primers for the identification of $P$. aeruginosa strains. Meanwhile, LasR and ecfX showed strong indication to be used as one of the species specific primers for $P$. aeruginosa identification with no cross-reaction or falsepositive/negative results showed on non-Pseudomonas species tested.

\section{Conclusions}

In conclusion, this study has confirmed and evaluated six isolate samples (13-1, 46-1, 10-R, 66-1, 00-1 and 67-1) and were identified as $P$. aeruginosa strains by amplification using PA-SS, PA-GS, Lasl/R, gyrB and ecfX primer pair targets using an uniplex PCR assay. Moreover, multiple primer pair targeted system used in this PCR assay would decrease the potential of unexpected misidentification including false-negative and false-positive results among all isolate samples. Here, high similarity (up to $99.0 \%$ ) obtained from sequence similarity of BLASTN analysis based on GeneBank NCBI database for pathogenic genes including Lasl/R, gyrB and ecfX primer pairs in all samples isolate. From this study, LasR and ecfX have been identified as the most suitable specific-species targeted primers in detecting $P$. aeruginosa in mastitis infected milk's sample. Moreover, this study has proved the reliability and reproducible results on species-specific identification of $P$. aeruginosa strains by using PA-SS, PA-GS, Lasl/R, gyrB and ecfX primer pairs.

\section{Conflicts of interest}

The author(s) declare(s) that there is no conflict of interest regarding the publication of this paper. 


\section{Funding statement}

This study was fully supported by the Fundamental Research Grant Scheme (FRGS) (FRGS/1/2018/STG05/UNISZA/02/1) and Special Research Grant Scheme (SRGS) (UniSZA/2017/SRGS/04) from Ministry of Higher Education Malaysia.

\section{Acknowledgments}

The authors fully acknowledged Ministry of Higher Education (MOHE) and Universiti Sultan Zainal Abidin for the approved fund which makes this important research possible. The authors also acknowledged Besut-Setiu Agropolitan Farm (BSA), Terengganu for the hospitality and cooperation during milk sampling. All authors read and approved the final version of manuscript.

\section{References}

[1] M. A. Al-kafaween et al., "Effects of Trigona honey on the gene expression profile of Pseudomonas aeruginosa ATCC 10145 and Streptococcus pyogenes ATCC 19615," Jordan J. Biol. Sci., vol. 13, no. 2, pp. 133-138, 2020.

[2] F. V. Bambeke, J.-M. Pagès, and V. J. Lee, "Inhibitors of bacterial efflux pumps as adjuvants in antibacterial therapy and diagnostic tools for detection of resistance by efflux," Front. Anti-Infection Drug Discov., vol. 1, pp. $138-175,2010$.

[3] D. Dong et al., "Rapid detection of Pseudomonas aeruginosa targeting the toxA gene in intensive care unit patients from Baijing, China," Front. Microbiol., vol. 6, pp. 1-7, 2015, doi: 10.3389/fmicb.2015.01100.

[4] H. Aghamollaei, M. M. Moghaddam, H. Kooshki, M. Heiat, R. Mirnejad, and N. S. Barzi, "Detection of Pseudomonas aeruginosa by a triplex polymerase chain reaction assay based on lasl/R and gyrB genes," $J$. Infect. Public Health, vol. 8, pp. 314-322, 2015, doi: http://dx.doi.org/10.1016/j.jiph.2015.03.003.

[5] Z. J. A. Alshalah, W. A. Al-Daraghi, and A. I. Khaleel, "Rapid detection for lasl and lasR genes Of Pseudomonas aeruginosa at deference Iraqi Hospitals by polymerase chain reaction ( PCR ) technique .," Int. J. Chem Tech Res., vol. 10, no. 1, pp. 409-414, 2017.

[6] S. Alhogail et al., "Rapid colorimetric detection of Pseudomonas aeruginosa in clinical isolates using a magnetic nanoparticle biosensor," ACS Omega, vol. 4, pp. 21684-21688, 2019, doi: 10.1021/acsomega.9b02080.

[7] Z. Zakaria et al., "Physicochemical composition, microbiological quality and consumers' acceptability of raw and pasteurized locally produced goat milk," Malaysian J. Fundam. Appl. Sci., vol. 16, no. 4, pp. 475-482, 2020, doi: $10.11113 /$ mjfas.v16n4.1842.

[8] Y. Tang et al., "Detection methods for Pseudomonas aeruginosa: history and future perspective," $R$. Soc. Chem. Adv., vol. 7, pp. 51789-51800, 2017, doi: 10.1039/c7ra09064a.

[9] A. Sharma, V. K. Gupta, and R. Pathania, "Efflux pump inhibitors for bacterial pathogens : From bench to bedside," Indian J. Med. Res., vol. 149, pp. 129-145, 2019, doi: 10.4103/ijmr.IJMR.

[10] K. I. Hassan and S. R. Abdullah, "Detection of Pseudomonas aeruginosa in clinical samples using PCR targeting ETA and gyrB genes," Baghdad Sci. J., vol. 15, no. 4, pp. 401-405, 2018, doi: 10.21123/bsj.2018.15.4.0401.

[11] S. N. Anuj et al., "Identification of Pseudomonas aeruginosa by a duplex real-time polymerase chain reaction assay targeting the ecfX and the gyrB genes," Diagn. Microbiol. Infect. Dis., vol. 63, pp. 127-131, 2009, doi: 10.1016/j.diagmicrobio.2008.09.018.

[12] X. Qin, J. Emerson, J. Stapp, L. Stapp, P. Abe, and J. L. Burns, "Use of real-time PCR with multiple targets to identify Pseudomonas aeruginosa and other nonfermenting Gram-negative bacilli from patients with cystic fibrosis," J. Clin. Microbiol., vol. 41, no. 9, pp. 4312-4317, 2003, doi: 10.1128/JCM.41.9.4312.

[13] R. Lavenir, D. Jocktane, F. Laurent, S. Nazaret, and B. Cournoyer, "Improved reliability of Pseudomonas aeruginosa PCR detection by the use of the species-specific ecfX gene target," J. Microbiol. Mthodsthods, vol. 70, pp. 20-29, 2007, doi: 10.1016/j.mimet.2007.03.008.

[14] C. S. Lee, K. Wetzel, T. Buckley, D. Wozniak, and J. Lee, "Rapid and sensitive detection of Pseudomonas aeruginosa in chlorinated water and aerosola targeting gyrB gene using real-time PCR," J. Appl. Microbiol. vol. 111, no. 4, pp. 893-903, 2011, doi: 10.1111/j.1365-2672.2011.05107.x.Rapid.

[15] M. Tam, T. Thi, D. Wibowo, and B. H. A. Rehm, "Pseudomonas aeruginosa biofilms," Int. J. Mol. Sci., vol. 21 p. 8671, 2020, doi: doi:10.3390/ijms21228671.

[16] M. E. Hillenbrand, P. P. Thompson, R. M. Q. Shanks, and R. P. Kowalski, "Validation of PCR for the detection of Pseudomonas aeruginosa from corneal samples," Int. J. Opthalmology, vol. 4, no. 3, pp. 262-268, 2011, doi: 10.3980/j.issn.2222-3959.2011.03.10.

[17] C. Colinon et al., "Detection and enumeration of Pseudomonas aeruginosa in soil and manure assessed by an ecfX qPCR assay," J. Appl. Microbiol., vol. 114, pp. 1734-1749, 2013, doi: 10.1111/jam.12189.

[18] M. Schuster, D. J. Sexton, S. P. Diggle, and E. P. Greenberg, "Acyl-homoserine lactone quorum sensing: From evolution to application," Annu. Rev. Microbiol., vol. 67, pp. 43-63, 2013, doi: 10.1146/annurev-micro$092412-155635$

[19] G. Girard and G. V. Bloemberg, "Central role of quorum sensing in regulating the production of pathogenicity factors in Pseudomonas aeruginosa," Futur. Med., vol. 3, no. 1, pp. 97-106, 2008, doi: 
10.2217/17460913.3.1.97

[20] S. T. Rutherford and B. L. Bassler, "Bacterial quorum sensing: Its role in virulence and possibilities for its control," Cold Spring Harb. Perspect. Med., vol. 2, pp. 1-25, 2012, doi: doi: 10.1101/cshperspect.a012427.

[21] L. C. M. Antunes, R. B. R. Ferreira, M. M. C. Buckner, and B. B. Finlay, "Quorum sensing in bacterial virulence," Microbiology, vol. 156, pp. 2271-2282, 2010, doi: 10.1099/mic.0.038794-0.

[22] J. L. da C. Lima, L. R. Alves, P. R. L. de A. Jacomé, J. P. B. Neto, M. A. V. Maciel, and M. M. C. de Morais, "Biofilm production by clinical isolates of Pseudomonas aeruginosa and structural changes in LasR protein of isolates non biofilm-producing," Brazilian J. Infect. Dis., vol. 22, no. 2, pp. 129-136, 2018, doi: 10.1016/j.bjid.2018.03.003

[23] A. Wan-Azemin, A. Kari, and N. Alias, "Assessment of subclinical mastitis effects on live weight, body condition score (BCS) and external udder measurements of dorper sheep," J. Teknol., vol. 83, no. 2, pp. 135142, 2021.

[24] M. Rossi-Tamisier, S. Benamar, D. Raoult, and P. E. Fournier, "Cautionary tale of using 16s rRNA gene sequence similarity values in identification of human-associated bacterial species," Int. J. Syst. Evol. Microbiol., vol. 65, no. 6, pp. 1929-1934, 2015, doi: 10.1099/ijs.0.000161.

[25] A. M. Abdalhamed, G. S. G. Zeedan, and H. A. A. A. Zeina, "Isolation and identification of bacteria causing mastitis in small ruminants and their susceptibility to antibiotics, honey, essential oils, and plant extracts," Vet. World, vol. 11, no. 3, pp. 355-362, 2018, doi: 10.14202/vetworld.2018.355-362.

[26] M. Rovai et al., "Identifying the major bacteria causing intramammary infections in individual milk samples of sheep and goats using traditional bacteria culturing and real-time polymerase chain reaction," J. Dairy Sci., vol. 97, pp. 5393-5400, 2014, doi: 10.3168/jds.2014-7988.

[27] M. Geetha, K. M. Palanivel, T. R. Gopalakrishnamurthy, S. Udayavel, and R. Ragavi, "An unsual occurrence of Pseudomonas mastitis in an ewe and its clinical management - a case report," Int. J. Sci. Environ., vol. 5, no. 6 , pp. 4618-4621, 2016

[28] E. J. Kelly and D. J. Wilson, "Pseudomonas aeruginosa mastitis in two goats associated with an essential oil - based teat dip," J. Vet. Diagnostic Investig., vol. 3, no. 10, pp. 1-3, 2016, doi: 10.1177/1040638716672255.

[29] G. Leitner and O. Krifucks, "Pseudomonas aeruginosa mastitis outbreaks in sheep and goat flocks : Antibody production and vaccination in a mouse model," Vet. Immunol. Immunopathol., vol. 119, pp. 198-203, 2007, doi: 10.1016/j.vetimm.2007.05.007.

[30] V. S. Mavrogianni, P. I. Menzies, I. A. Fragkou, and G. C. Fthenakis, "Principles of mastitis treatment in sheep and goats," Vet. Clin. Food Anim., vol. 27, pp. 115-120, 2011, doi: 10.1016/j.cvfa.2010.10.010.

[31] J. G. Al-ahmadi and Z. R. Roodsari, "Fast and specific detection of Pseudomonas aeruginosa from other Pseudomonas species by PCR," Ann. Burns Fire Disasters, vol. 29, no. 4, pp. 264-267, 2016.

[32] L. Scaccabarozzi et al., "Pseudomonas aeruginosa in dairy goats: Genotypic and phenotypic comparison of intramammary and environmental isolates," PLoS One, vol. 10, no. 11, pp. 1-23, 2015, doi: 10.1371/journal.pone.0142973.

[33] E. A. Wright et al., "Divergence of a strain of Pseudomonas aeruginosa during an outbreak of ovine mastitis," Vet. Microbiol., vol. 175, pp. 105-113, 2015, doi: 10.1016/j.vetmic.2014.11.011.

[34] V. Cattoir, A. Gilibert, J. -m. Le Glaunec, N. Launay, L. Bait-mérabet, and P. Legrand, "Rapid detection of Pseudomonas aeruginosa from positive blood cultures by quantitative PCR," Ann. Clin. Microbiol. Antimicrob., vol. 9, no. 21, pp. 1-5, 2010, doi: doi:10.1186/1476-0711-9-21

[35] A. K. Bej, M. H. Mahbubani, J. L. Dicesare, and R. M. Atlas, "Polymerase chain reaction-gene probe detection of microorganisms by using filter-concentrated samples," Appl. Environ. Microbiol., vol. 57, no. 12, pp. 35293534, 1991.

[36] R. K. Saiki et al., "Primer-directed enzymatic amplification of DNA with a thermostable DNA polymerase," Science (80-. )., vol. 239, pp. 487-491, 1988, doi: DOI: 10.1126/science.239.4839.487 ARTICLE.

[37] T. Spilker, T. Coenye, P. Vandamme, and J. J. Lipuma, "PCR-based assay for differentiation of Pseudomonas aeruginosa from other Pseudomonas species recovered from cystic fibrosis patients," J. Clin. Microbiol., vol. 42, no. 5, pp. 2074-2079, 2004, doi: 10.1128/JCM.42.5.2074.

[38] H. O. M. Al-dahmoshi, N. S. Al-khafaji, A. A. Jeyad, H. K. Shareef, and R. F. Al-jebori, "Molecular detection of some virulence traits among Pseudomonas aeruginosa isolates, Hilla-Iraq," Biomed. Pharmacol. J., vol. 11, no. 2, pp. 835-842, 2018, doi: $10.13005 / \mathrm{bpj} / 1439$.

[39] A. E. LaBauve and M. J. Wargo, "Growth and laboratory maintenance of Pseudomonas aeruginosa," Curr. Protoc. Microbiol., vol. 25, no. 1, pp. 1-11, 2012, doi: 10.1002/9780471729259.mc06e01s25.Growth.

[40] D. M. Whiley, S. B. Lambert, S. Bialasiewicz, N. Goire, M. D. Nissen, and T. P. Sloots, "False-negative results in nucleic acid amplification tests - Do we need to routinely use two genetic targets in all assays to overcome problems caused by sequence variation?," Crit. Rev. Microbiol., vol. 34, no. 2, pp. 71-76, 2008, doi: 10.1080/10408410801960913.

[41] D. M. Whiley, S. B. Lambert, S. Bialasiewicz, and N. Goire, "False-negative results in nucleic acid amplification tests - Do we need to routinely use two genetic targets in all assays to overcome problems caused by sequence variation?," Crit. Rev. Microbiol., vol. 34, pp. 71-76, 2008, doi: 10.1080/10408410801960913.

[42] M. Salman, A. Ali, and A. Haque, "A novel multiplex PCR for detection of Pseudomonas aeruginosa: A major cause of wound infections," Pakistan J. Med. Sci., vol. 29, no. 4, pp. 957-961, 2013, doi: doi: http://dx.doi.org/10.12669/pjms.294.3652 How.

[43] M. Motoshima et al., "Rapid and accurate detection of Pseudomonas aeruginosa by real-time polymerase chain reaction with melting curve analysis targeting gyrB gene," Diagn. Microbiol. Infect. Dis., vol. 58, pp. 5358, 2007, doi: 10.1016/j.diagmicrobio.2006.11.007.

[44] D. Subedi, A. K. Vijay, G. S. Kohli, S. A. Rice, and M. Willcox, "Comparative genomics of clinical strains of Pseudomonas aeruginosa strains isolated from different geographic sites," Sci. Rep., vol. 8, pp. 1-14, 2018, doi: 10.1038/s41598-018-34020-7.

[45] V. S. Nikbin, M. M. Aslani, Z. Sharafi, M. Hashemipour, F. Shahcheraghi, and G. H. Ebrahimipour, "Molecular identification and detection of virulence genes among Pseudomonas aeruginosa isolated from different 
infectious origins," Iran. J. Microbiol., vol. 4, no. 3, pp. 118-123, 2012

[46] M. A. Khattab, M. S. Nour, and N. M. Elsheshtawy, "Genetic identification of Pseudomonas aeruginosa virulence genes among different isolates," J. Microb. Biochem. Technol., vol. 7, no. 5, pp. 274-277, 2015, doi: 10.4172/1948-5948.1000224.

[47] S. G. Mulamattathil, C. Bezuidenhout, M. Mbewe, and C. N. A. Ateba, "Isolation of environmental bacteria from surface and drinking water in Mafikeng, South Africa, and characterization using their antibiotic resistance profiles," Journals Pathog., vol. 2014, pp. 1-11, 2014, doi: 10.1155/2014/371208.

[48] M. Fukushima, K. Kakinuma, and R. Kawaguchi, "Phylogenetic analysis of Salmonella, Shigella, and Escherichia coli strains on the basis of the gyrB gene sequence," J. Clin. Microbiol., vol. 40, no. 8, pp. 27792785, 2002, doi: 10.1128/JCM.40.8.2779.

[49] P. Kiratisin, K. D. Tucker, and L. Passador, "LasR , a transcriptional activator of Pseudomonas aeruginosa virulence genes, functions as a multimer," J. Bacterology, vol. 184, no. 17, pp. 4912-4919, 2002, doi: 10.1128/JB.184.17.4912.

[50] F. Longo et al., "A new transcriptional repressor of the Pseudomonas aeruginosa quorum sensing receptor gene lasR," PLoS One, vol. 8, no. 7, pp. 1-9, 2013, doi: 10.1371/journal.pone.0069554.

[51] D. Bortolotti et al., "Conjugation of LasR quorum-sensing inhibitors with ciprofloxacin decreases the antibiotic tolerance of P . aeruginosa clinical strains," J. Chem., vol. 2019, pp. 1-13, 2019, doi: 10.1155/2019/8143739.

[52] H. M. Aboushleib, H. M. Omar, R. Abozahra, A. Elsheredy, and K. Baraka, "Correlation of quorum sensing and virulence factors in Pseudomonas aeruginosa isolates in Egypt," J. Infect. Dev. Ctries., vol. 9, no. 10, pp. 1091-1099, 2015, doi: 10.3855/jidc.6492.

[53] G. Mangiaterra et al., "Detection of viable but non-culturable Pseudomonas aeruginosa in cystic fibrosis by qPCR : a validation study," BMC Infect. Dis., vol. 18, no. 701, pp. 1-7, 2018, doi: 10.1186/s12879-018-36129 (2018).

[54] P. Deschaght, S. daele Van, F. D. Baets, and M. Vaneechoutte, "PCR and the detection of Pseudomonas aeruginosa in respiratory samples of CF patients. A literature review," J. Cyst. Fibros., vol. 10, pp. 293-297, 2011, doi: 10.1016/j.jcf.2011.05.004.

[55] H. J. Choi et al., "Improved PCR for identification of Pseudomonas aeruginosa," Appl. Microbiol. Biotechnol., vol. 97, pp. 3643-3651, 2013, doi: 10.1007/s00253-013-4709-0. 